MIGRACIONES INTERNACIONALES, VOL. 11, ART. 6, 2020 e-ISSN 2594-0279 https://doi.org/10.33679/rmi.v1i1.1846

\title{
Climate Change and Forced Migration
}

\section{Cambio climático y migración forzada}

Shirley Llain Arenilla ${ }^{1} \&$ Cindy Hawkins Rada ${ }^{2}$

\section{ABSTRACT}

The population of environmentally displaced people has increased recently, thus this article aims to address the challenges climate change may impose on Nation-States concerning human rights in relation to forced migration. The relationship between climate change and forced migration will be studied in order to present the problems arising from the allocation of international responsibility among States and the international protection (or the lack thereof) of "Climate Refugees" and stateless persons caused by the disappearance of NationStates under climate change; solutions will be proposed under the existing International Human Rights Law.

Keywords: 1. climate change, 2. forced migration, 3. climate refugees, 4. statelessness, 5. environmental displacement.

\section{RESUMEN}

La población de desplazados ambientales se ha incrementado en los últimos años, por lo que este artículo aborda los desafíos que el cambio climático impone a los Estados respecto a los derechos humanos relacionados con la migración forzada. Se estudiará la relación entre cambio climático y migración forzada con el fin de presentar los problemas derivados de la responsabilidad internacional de los Estados y la protección internacional (o la falta de ella) de "refugiados del cambio climático" y apátridas, causados por la desaparición de los Estados como consecuencia del cambio climático; se propondrán soluciones desde el derecho internacional de los derechos humanos.

Palabras clave: 1. cambio climático, 2. migración forzada, 3. refugiados del cambio climático, 4. apátridia, 5. desplazamiento ambiental.

Date received: February 16, 2018

Date accepted: July 02, 2018

Published online: May 28, 2020

\footnotetext{
${ }^{1}$ Universidad del Norte, Colombia, sllain@uninorte.edu.co

${ }^{2}$ University of Georgia, United States, cindy.hawkins@uga.edu, https://orcid.org/0000$\underline{0003-3500-6827}$
} 


\section{INTRODUCTION}

In the last decades, climate change has been one of the most important and controversial issues of discussion among scientists, governments and international organizations considering the potentially threatening consequences that this phenomenon may bring to the life forms of this planet. This topic has been on the agenda of the United Nations since the first World Climate Conference, in 1979. Further, it was included in the 2030 Agenda for Sustainable Development, where Goal 13 urges us to "[...] take urgent action to combat climate change and its impacts" (UN General Assembly, 2015, p. 14). In this regard, changing weather patterns, rising sea level, and extreme weather events have been recognized by the UN General Assembly (2015) as consequences of climate change, which are circumstances that affect all nations and especially the poorest, most vulnerable people.

Recently, the first international agreement on climate change was negotiated and signed. This was the result of the Paris Climate Conference (COP21) in December 2015, held by the United Nations, where 195 countries participated and "[...] adopted the first-ever universal, legally binding global climate deal" (European Commission, 2016, para. 4). It has been said that this was an enormous effort to acknowledge the existence and negative effects of climate change and, at that moment, the agreement recognized several issues, among which the relationship between climate change, forced migration, and human rights was counted. Accordingly, the Paris Agreement establishes that:

Acknowledging that climate change is a common concern of humankind, Parties should, when taking action to address climate change, respect, promote and consider their respective obligations on human rights, the right to health, the rights of indigenous peoples, local communities, migrants, children, persons with disabilities and people in vulnerable situations and the right to development, as well as gender equality, empowerment of women and intergenerational equity (United Nations, 2015, pp.1-2).

However, this recognition is insufficient since the agreement lacks the depth to create a regulatory framework that promotes the defense of the rights of those individuals forced to flee their countries due to climate change. As a result, this paper aims to address the challenges climate change may impose on Nation-States concerning human rights, especially in relation to those who must migrate across borders. Therefore, the relationship between climate change and forced migration will be studied, in order to present the problems arising from the allocation of international responsibility among States on this subject and the international protection (or the lack thereof) that instruments such as the Convention on the Status of Refugees of 1951, the 1984 Cartagena Declaration, and the Organization of African Unity (OAU) Convention might offer to climate migrants. Finally, the potential increase of stateless persons caused by the disappearance of Nation-States under climate change and the normative framework that should be implemented to provide an effective solution to this situation will be analyzed. 


\section{ESTABLISHING THE RELATIONSHIP BETWEEN CLIMATE CHANGE AND FORCED MIGRATION}

Currently, the study of the relationship between climate change and forced migration has led to the conclusion that the impacts of climate change, especially those related to water shortage and hostile weather conditions, will make life conditions extremely difficult in some parts of the world (considering it will cause loss of livelihood, employment, lands, infrastructure, violence, and conflict, among others), or it will make many places uninhabitable, which will bring as a consequence an increase in forced migration (Toscano, 2017). ${ }^{3}$

According to Zetter (2015) extreme environmental events will cause, directly and indirectly, an increase in human migration and displacement, because of three conditions described by the United Nations Environment Programme (UNEP): 1) the effects of warming, which will affect agricultural production, and will produce degradation of the ecosystem; 2) the increase in extreme weather events - especially heavy rainfall and resulting flash or river floods in tropical regions-, and 3) the sea-level rise, which will permanently destroy extensive low-lying coastal areas (Zetter, 2015, pp. 3-4).

However, it is important to address that many scholars consider that more research is needed in the establishment of a relationship between climate change and migration. They have put forward claims such as the uncertainty of the effects of climate change on migration, the question around the exact number of people who will be migrating because of climate change, ${ }^{4}$ and the difficulties in distinguishing populations forced to migrate because of climate change from populations forced to migrate as a result of environmental factors or other types of factors. In addition, multi-causality has led scholars to point out that climate change is just one of the factors that exacerbate migration, mostly on a temporal basis and within the same country (Thornton, 2012, p. 148; Kibreab, 2009, pp. 360, 388).

It has to be acknowledged that climate change may not be the only or main driver of migration, but it is a source of pending risk that needs to be considered in any national or international policy designed to address the consequences of climate change. In this respect, Toscano (2017) asserted that climate change is a "threat multiplier" and multi-causality does not mean that climate change is not an important factor that induces migration. Thus, despite the lack of consensus on the main reason for human migration, the effects of climate change (i.e., droughts, floods, loss of land, rising temperatures, and rising sea levels) will force

\footnotetext{
${ }^{3}$ According to Toscano (2017) forced migration within and across the borders "will become increasingly commonplace due to the repercussions of climate change" (p. 140).

${ }^{4}$ Even though different estimations have been made by several scholars such as Meyers (1997), Stern (2007), Aid (2007), and UNCHR (2012), the complexity of climate change makes very difficult to determine an exact number of environmentally displaced people (Fujibayashi \& Nakayama, 2017, p. 1; Toscano, 2017, p. 474).
} 
migration or will leave populations to endure its direct impacts (Toscano, 2017, p. 462; Kuusipalo, 2017, p. 618).

In terms of migration categories, climate change will produce internally displaced persons (IDPs), climate migrants, and statelessness. In addition, researchers have established a new category: "trapped population," which is encompassed by persons who are not able to migrate either internally or externally due to the lack of financial means or other factors (Black, Arnell, Adger, Thomas, \& Geddes, 2012; Black \& Collyer, 2014; Kuusipalo, 2017). Consequently, the link between climate change and migration exists and, as reported by the Office of the United Nations High Commissioner for Human Rights - OHCHR (2009), it brings drastic consequences on fundamental human rights such as the right to life, food, work, and housing, with the population in low-income countries being the most affected.

\section{CHALLENGES IN THE RESPONSE TO CLIMATE CHANGE IMPACTS IN FORCED MIGRATION}

The international protection of climate migrants faces great challenges. The first one is the political will of States, especially the developed countries, to put in place legal and technical measures to prevent or mitigate the consequences of climate change in relation to migration. The second one is the lack of a legal framework designed specifically to address the rights of climate migrants and the duties of Nation-States towards them.

\section{Political Will}

At this stage, the question is whether there is a political will between Nation-States to reach a consensus to give a real and meaningful solution to climate migration. The answer somehow has been influenced by the on-going debate among Nation-States, NGOs, scholars, and International Organizations around the intensity of the effects of climate change, which causes alterations to the decision-making process of Nation-States in relation to possible solutions. The Intergovernmental Panel on Climate Change (2014) has pointed out that "[...] responding to climate-related risks involves decision making in a changing world, with continuing uncertainty about the severity and timing of climate-change impacts and with limits to the effectiveness of adaptation" (Intergovernmental Panel on Climate Change, 2014 , p. 9). In this respect, the debate among scholars is composed by those who consider that one of the impacts of climate change is forced migration (maximalist) and those who consider that migration on account of climate change will be only "indirect or multifaceted" (minimalist) (Gogarty, 2011, p. 175; Thornton, 2012, p. 149; Mayer, 2013, p. 3).

Consequently, while there is recognition by Nation-States regarding climate change as a new factor of migration, the uncertainty about the scope of the problem has prevented them from reaching a consensus over possible solutions from the financial and legal viewpoint. 
According to Wyman (2013), precisely, these two aspects are gaps in the law and policy on climate change migration. Wyman (2013) describes them as the "rights gap" and the "funding gap," where the first refers to the "lack of a right in existing law to remain permanently in another country due to environmental conditions in the home country" and the latter to the "lack of a dedicated source of international funding to help offset the costs that developing countries may incur in dealing with climate change migration" (2013, p. 169).

In this respect, putting the topic of climate change and forced migration at the center of the political discussion will set the path policy makers should follow in order to design methods that will provide financial and legal protection to the populations vulnerable to these situations. In addition, it is necessary to consider migration as an adaptation strategy:

"[...] where key policy responses to environmental migration should include protection and supportive services for migrants, such as investing in the environmentally impacted regions to reduce the flow of migrants, investing in host regions to help relieve them of the burdens on infrastructure due to receiving a substantial number of migrants, and considering rights-based resettlement efforts for populations directly displaced by the effects of climate change" (Toscano, 2017, pp. 474-475).

\section{Legal Framework}

Building a new legal framework to address climate migration, in which there is recognition of a new category of persons worthy of international protection or finding legal protection for environmentally displaced people within the international refugee law framework has been proven extremely difficult.

In the first place, political will is needed, as explain by Feijen (2012), to get Nation-States to agree to share burdens and to accept to give immigration status to those people displaced across borders because of climate change (2012, pp. 63-64). In the second place, even though some commentators such as Burleson (2010) have affirmed that amending the existing refugee law framework will "[...] end the legal limbo that future ecomigrants face" (2010, p. 22), the lack of political will is evident and this option seems less plausible. ${ }^{5}$ Nowadays, the fundamental structure of refugee protection is in crisis, and rather than being willing to negotiate a new agreement to offer more protection to vulnerable populations, governments are negotiating agreements that allow them to circumvent principles as

\footnotetext{
${ }^{5}$ According to Thornton (2012), “A new generation of legal and policy scholarship has questioned the likelihood or utility of new or revised treaty instruments and with it a protection-based approach" (2012, p. 154). At the same time, Warren (2016) expresses that some commentators fear that amending the Convention will diminish the current protection for refugees (2016, p. 2125).
} 
6 Climate Change and Forced Migration

important as the principle of non-refoulement. ${ }^{6}$ In the third place, the legal possibility or even the convenience of using international refugee law to afford protection to climate migrants, also called by some scholars as "climate refugees," is highly controversial.

With regard to this last issue, it is important to point out that under international refugee law, mostly the 1951 Convention on the Status of Refugees (hereinafter the 1951 Convention) and the 1967 Protocol Relating to the Status of Refugees, the concept of refugee is very restrictive and even more so if it is considered that many States "tend to establish policies to keep refugees outside their jurisdiction, and, consequently, imperil the protection set up by the 1951 Convention" (Llain, 2015, p. 289). Consequently, it does not include persons in need of international protection beyond those individuals who possess a wellfounded fear of being persecuted because of their race, religion, nationality, membership in a particular social group or political opinion, and who for one of these reasons, are outside their country of nationality or habitual residence, and are unable or unwilling to avail themselves of the protection of that country.

The report of the Nansen Conference on Climate Change and Displacement stresses that "A fundamental concern is that while refugees from war and persecution are protected by international conventions, it is unclear what laws and policies protect people displaced across international borders by extreme weather events" (Norwegian Refugee Council, 2011, p. 3).

In addition, even though "climate refugees" have a well-founded fear for fleeing their countries and can be considered as members of a particular social group, (one can argue they share as a common characteristic being affected by climate change, e.g. extreme weather or some other extreme event), authors like McAdam (2011) have stated that the concept provided by the 1951 Convention does not apply to climate refugees because climate change cannot be characterized as "persecution." Thus, persecution is a fundamental element of the concept of refugees. In this case, there is not a "persecutor" who may be identified, ${ }^{8}$ and the

\footnotetext{
${ }^{6}$ The most recent example of this situation is the European Union-Turkey agreement on refugees that allows Greece to return "irregular migrants" to Turkey. As reported by Rankin (2016), the Council of Europe has condemned the agreement claiming that "[...] [it] exceeds the limits of what is permissible under International Law" (para. 1).

7 This term, along with "environmental refugees," is normally used to refer to "[...] people who have been forced to leave their traditional habitat, temporarily or permanently, because of a marked environmental disruption that jeopardized their existence and/or seriously affected the quality of their life', (Essam El-Hinnawi, 1985, p. 4. Quoted by Bates, 2002, p. 466).

${ }^{8}$ See also: Wyman (2013) who considers that climate change is not a form of persecution (p. 179). Also, Gogarty, (2011), explaining that advocacy to have climate migrants be recognized within the 1951 Convention has been futile because critics do not consider climate change the main factor for displacement, and which it is the main factor, it only causes temporary displacement (2011, p. 172).
} 
persecution needs to be on account of one of the five motives set in the 1951 Convention. McAdam (2011), also reasoned that "[...] an argument that people affected by its impacts could constitute a 'particular social group' would be difficult to establish, because the law requires that the group must be connected by a fundamental, immutable characteristic other than the risk of persecution itself" (2011, p. 13).

\section{A SEPARATE CHALLENGE: STATELESSNESS AS A CONSEQUENCE OF CLIMATE CHANGE}

Statelessness has become an imminent risk due to climate change, as the increase in sea levels may sink, in the future, low-lying States, known as Sinking Island States (Vidas, 2014). Nations such as The Maldives, Kiribati, Tuvalu, and the Marshall Islands have experienced examples of this reality. In those States, the population will have to leave their countries because of climate change and will become stateless when the existence of their State ends (United Nations High Commissioner for Refugees, 2009). Even though some authors doubt that this situation will actually happen soon (Barnett, 2017), the uninhabitability of certain territories is beginning to cause forced migration, considering cases such as the Carteret Islands, where 1,000 residents were evacuated to Bougainville as a consequence of storm-related erosion and saltwater intrusion (Brown, 2007).

This impact of climate change will particularly affect islands in the Pacific. Thus, by 2050, 665,000 to 1.7 million people in the Pacific Islands could be forced to migrate to another country. Estimates have indicated that Kiribati and The Maldives could disappear completely in the next 30 to 60 years, as well as Tuvalu, which may disappear in the following 50 years (Tomkiw, 2015).

Also, it is possible to say that the consequences of climate change, and particularly those related to rising sea levels, could begin before expected because the territory could become uninhabitable before its disappearance. Some States have already been affected by climate change impacts such as temporary floods, tropical storms, tides, and coastal erosion: phenomena that are able to destroy the territory of a State. For example, Tuvalu is affected periodically by floods causing contamination and the destruction of houses. Similarly, in 2004, The Maldives were almost completely submerged, as a result of a tsunami, equally since then the tides have flooded 80 of the islands (Park \& UNHCR, 2011).

\section{Statehood and Climate Change}

As explained above, there is a probability that statelessness will increase due to the disappearance of certain States. Under Customary International Law, a State is considered as such, when it has: 1) a defined territory, 2) a permanent population, 3) a government, and 4) capacity to enter relations with other States. This concept has been established in 
international instruments such as the 1933 Montevideo Convention on the Rights and Duties of States.

In these terms, territory is a key element in the concept of State. Therefore, according to the terms set out by International Law, an entity cannot claim statehood without a territory. (Crawford, 1977; Zounuzy, 2012). Furthermore, it should be considered that without it, there is an impossibility to meet the other elements in the concept of State, especially because of the relationship between the territory and the permanent population, as inhabitants share an intimate bond with the territory they live in. This does not mean that the entire population must live in the territory of the State; considering that the criteria in the Convention are independent, at least a portion of the population must live in the territory, and that is why an implied nexus between the State's territory and the permanent population exists (Jan, 2011).

In this regard, the Sinking Island States case is unique, because of the lack of a successor State to replace the preceding one. Even when International Law applies to the continuity presumption, there are no precedents for the loss of the entire territory of a State or the migration of its entire population (McAdam, 2010), creating de jure statelessness for the people involved because they could not become nationals of other States according to the receiving State's laws (Park \& UNHCR, 2011).

International law has not developed any precedence for the disappearance of a State; it has only regulated cases of: "(i) absorption (by another State), merger (with another State) and dissolution (with the emergence of successor States)" (McAdam, 2010, p. 2), and the difference between these cases and the extinction of a State because of climate change is that "[...] the territory it abandons will not (cannot) be assumed by any other State" (McAdam, 2010 , p. 2). In this sense, the principle of presumption of continuity of State existence cannot overrule that the territory becomes uninhabitable, a necessary condition of statehood. If the population of a Nation-State with uninhabitable or disappeared territory has no other nationality, they will be de jure stateless, and the difficulty regarding statelessness is not just the right to nationality, but other rights that depend on the recognition as a national of a certain State (Alexander \& Simon, 2014).

On the other hand, international human rights law has established the duty of readmission as an obligation regarding statelessness. The duty of readmission relates to the capability of Nations-States to readmitting their nationals as a minimal requirement to prevent statelessness. Considering this duty, it would be impossible for States with an uninhabitable or disappeared territory to have the capability of readmitting their nationals who suffered from the impacts of climate change (Alexander \& Simon, 2017). 


\section{POSSIBLE SOLUTIONS TO ADDRESS CLIMATE MIGRATION}

\section{To Explore Opportunities of Protection Within the International Human Rights Law Framework}

Nation-States have concentrated their efforts on the design of prevention, mitigation, and adaptation plans to cope with climate change and its adverse impacts. In addition, international cooperation has been set in terms of funding those plans and projects in least developed countries. However, the main issue, concerning human lives, is how to provide legal protection to the populations affected by climate change to guarantee their fundamental human rights.

In this context, providing legal protection means not only establishing policies to ensure financial, logistical and technical assistance for adaptation, or even relocation, but also interpreting migration policies in accordance with international human rights obligations to facilitate the exercise of the climate migrant's rights. Therefore, it is important to explore opportunities of protection within the international human rights law framework, which will not need political will for amendments or the creation of new rules and which can be implemented through the regional human rights systems.

Concurring with this idea, Chapman (2010) stated that regional systems (European, InterAmerican and African systems) have the potential to be used to address issues in regard to climate change and, "[...] in evaluating the potential fate of a petition based on human rights violations resulting from climate change, each of the three established systems has its own strengths" (2010, p. 37).

For instance, in the Inter-American Human Rights System, the general duty of prevention is well developed in the doctrine and jurisprudence of both the Inter-American Commission on Human Rights (IACHR) and the Inter-American Court of Human Rights (IACtHR). The IACtHR has ruled that the Contracting States (of the American Convention on Human Rights) have the obligation to take reasonable steps to prevent violations of human rights. ${ }^{9}$ This means that in a situation of real, actual, and immediate risk of violation of human rights, known by the State and its authorities, the State must take all the necessary and reasonable legal, political, administrative, and cultural measures to prevent and avoid that risk. ${ }^{10}$

Applying this reasoning, climate change can be considered a genuine, present, and immediate risk to the human rights of the individuals forced to flee their places of origin on account of this factor: a risk that is known by Nation-States. Therefore, they have the responsibility to take actions to prevent the impacts of climate change (United Nations,

\footnotetext{
${ }^{9}$ See Case of Osorio Rivera and Family members $v$. Peru (IACtHR, 2013b).

${ }^{10} \mathrm{Cf}$. Case of the Xákmok Kásek Indigenous Community. v. Paraguay (IACtHR, 2010), Case of Luna López v. Honduras (IACtHR, 2013a), and Case of the Pueblo Bello Massacre $v$. Colombia (IACtHR, 2006a).
} 
2015) in regard to forced migration, adopting legal norms as well as other types of acts to assist those affected in maintaining their rights. ${ }^{11}$

In addition, regional instruments such as the Additional Protocol to the American Convention on Human Rights in the Area of Economic, Social and Cultural Rights "Protocol of San Salvador" in its Article 11, recognizes the right to a healthy environment, which also had been used as the base for petitions before the African Commission on Human and Peoples Rights (ACHPR), an entity that has found States in violation of their associated obligations (Chapman, 2010).

In the Inter-American System, although few cases exist on this subject, ${ }^{12}$ the IACtHR has noted that an undeniable link between the protection of the environment and the enjoyment of other human rights can be found..$^{13}$ Also, the IACtHR (2009) has said that "the ways in which the environmental degradation and the adverse effects of climate change have impaired the effective enjoyment of human rights in the continent has been the subject of discussion by the General Assembly of the Organization of American States and the United Nations"14 (para. 148).

Furthermore, as explained by the Asociación Americana para la Defensa del Ambiente (Inter-American Association for Environmental Defense) (2008), the recognition of this right, as a human right, implies that States must make resources available and take actions to guarantee this. In addition to the above, it is noteworthy that in the Inter-American Human Rights System, the right to a healthy environment reaches a connotation beyond being a human right, as the Inter-American Democratic Charter, in its Article 15, also recognizes it as an aim of democracy (Asociación Americana para la Defensa del Ambiente, 2008).

Consequently, an approach based on human rights needs to guide the design and implementation of the law and policy as well as the political discourse. According to

\footnotetext{
${ }^{11}$ Naser (2010) considered that in light of the obligations to respect, protect, and fulfill set up under international human rights law, governments have "[...] to adopt legal measures at the local and national levels to coordinate disaster response and relocation management" (p. 114).

${ }^{12}$ The pronouncements of the Court about the right to a healthy environment relates to Indigenous Communities issues and their view with respect to the right of property of their lands and natural resources, as reflected in the Cases of Mayagna (Sumo) Awas Tingni $v$. Nicaragua (IACtHR, 2001), Yakye Axa Indigenous Community v. Paraguay (IACtHR, 2005), and Sawhoyamaxa Indigenous Community $v$. Paraguay (IACtHR, 2006b).

${ }^{13}$ In its recent Advisory Opinion OC 23/17, the IACtHR (2017) highlighted this link, as a result of the interdependence and indivisibility between human rights, the environment, and the sustainable development. The Court quoted the resolution 35/17 of the Human Rights Council to emphasize that climate change produces adverse effects in the rights to life, health, food, water, adequate housing, and self-determination (2017, para. 54).

${ }^{14}$ See Case of Kawas Fernández v. Honduras (IACtHR, 2009).
} 
Aminzadeh (2007), this approach "[...] would integrate the theoretical and advocacy approaches of environmental law and human rights law" (2007, p. 258). In this respect, strategies such as "[...] 1) the application of procedural rights found in International Human rights Law to climate change litigation; 2) the recognition of a distinct right to environmental well-being; and 3) the re-interpretation of existing human rights in the environmental context" may be viable to offer an effective solution for the aforementioned protection of climate migrants (Aminzadeh, 2007, p. 245).

\section{Evolutionary Interpretation of the Principle of Non-Refoulement}

As explained earlier the current international refugee law framework does not fit climate migrants. Under this scenario, the most cost-effective solution is to give the principle of nonrefoulement an evolutionary interpretation, in order to expand the protections offered by the principle to climate migrants. ${ }^{15}$ In this regard, it is important to point out that for purposes of the interpretation of international human rights law treaties, the same should be done attending the pro homine principle "[...] that is, that they should be interpreted in the way which is most protective of human rights" (Lixinski, 2010, p. 588).

Thus, an evolutionary interpretation of the principle of non-refoulement, based on the concept of respect to human dignity, may lead to the establishment of international responsibility of States in this topic and to create a cause of action for climate migrants when they are denied protection. Regarding this topic, the IACHR has stated that respect for the inherent dignity of the person is the principle on which the fundamental protections of the right to life and the preservation of physical well-being are based. The conditions of severe environmental pollution, which can cause serious physical illness, disability, and suffering to the local population, are incompatible with the right to be respected as a human being (Asociación Americana para la Defensa del Ambiente, 2008, p. 54).

Accordingly, the evolutionary interpretation of the rights consecrated in international human rights law instruments must play an important role in giving the principle of nonrefoulement an extended scope. International human rights bodies, such as the IACtHR (1999), have used this form of interpretation, explaining that "[...] human rights treaties are living instruments whose interpretation must consider the changes over time and presentday conditions"16 (1999, para. 114).

\footnotetext{
${ }^{15}$ Analogously, for Kälin and Schrepfer (2002), “[...] the Non-Refoulement provisions of human rights law may prove particularly significant in this regard" (2002, p. 25).

${ }^{16}$ IACtHR (1999). The Right to Information on Consular Assistance in the Framework of the Guarantees of the due Process of Law. Advisory Opinion OC-16/99 of October 1, 1999. Series A No. 16. Para. 114. In this Advisory Opinion the IACtHR (1999) stated that other courts such as the International Court of Justice and the European Court of Human Rights,
} 


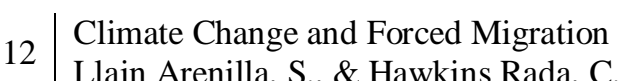

As a consequence, when considering the protection that may be provided to climate migrants, the applicable international instruments should be connected with the circumstances of the case; that climate change is a real and imminent risk, as explained earlier, known by States; and that these circumstances cause several violations to human rights. According to Naser (2010), migrants in this situation are especially affected in their rights to life, health, food, and shelter. For that reason, there is a growing insistence that a "policy framework should be developed to protect, respect, and promote the human rights of the affected people" (2010, p. 119).

On this subject, McAdam (2011) stated that the best way to apply the principle of nonrefoulement to climate change is by connecting it to the right to life and the right to not to be subjected to torture or cruel, inhuman or degrading treatment or punishment because those rights " $[. .$.$] are clearly recognized in International Law as giving rise to such an obligation,$ and which have been incorporated into a number of domestic complementary protection regimes" (2011, p. 18). As a result, States will have the general duty to protect and not return or expel vulnerable populations to places where their lives will be at risk of harm due to the effects of climate change.

Finally, changes over time and present-day conditions have been a cause to urge for an expansion of the concept of refugee. For instance, the United Nations High Commissioner for Refugees has exhorted States to implement expanded refugee definitions such as those adopted in the Cartagena Declaration or the OAU Convention Governing the Specific Aspects of Refugee Problems in Africa (Llain, 2015, p. 290). Under those instruments, additional reasons may trigger the international protection available for refugees, such as external aggression, occupation, foreign domination or events seriously disturbing public order in either a part or the whole country of origin or nationality, and the massive violation of human rights (added by the Cartagena Declaration). It is an unresolved task to analyze whether factors such as "events seriously disturbing public order" may be interpreted in favor of giving international protection under the status of refugee to those suffering from the adverse impacts of climate change. ${ }^{17}$ However, Warren (2016) has pointed out that "under either expanded definition, a natural disaster could arguably constitute a circumstance that "disturb[s] the public order," but neither was explicitly intended to cover environmental displacement" (2016, p. 2123). Consequently, it is time, once again, to call

in Tyrer $v$. United Kingdom (1978), Marckx v. Belgium (1979), and Loizidou v. Turkey (1995) have used this criterion.

${ }^{17}$ In this regard, the Brazil Declaration in the frame of the Cartagena Declaration, states that "[...] in light of the new challenges posed by climate change and natural disasters, as well as by displacement of persons across borders that these phenomena may generate, UNHCR is requested to prepare a study on the subject with the aim of supporting the adoption of appropriate national and regional measures [...], within the framework of its mandate" (United Nations High Commissioner for Refugees, 2004, p. 18). 
for a broader interpretation that may introduce, at both municipal and international law levels, considerations related to the status of climate migrants.

Complementary Protection, Durable Solutions: Voluntary Repatriation, Resettlement, and Integration

The principle of non-refoulement provides an additional obligation that could be a solution to climate migrants, considering the universal refugee instruments and customary international refugee law. The complementary protection refers to the mechanism to grant international protection to persons who do not meet the established requirements to be considered as a refugee in the scope of the 1951 Convention (Mandal, 2005).

This obligation is based on the provisions prohibiting the expulsion of individuals from the territory of a Nation-State, and the international responsibility of a State on acts or omissions when individuals are in need of international protection because of the risk to their human rights (Mandal, 2005).

In this sense, Nation-States must develop systems of complementary protection, which seek to apply international law obligations and prevent the violation of the human rights of those facing the climate change impacts. Even though the complementary protection could need a substantial development to address climate change challenges, it does not preclude climate change from being recognized as a source of inhuman treatment to obligate NationStates to grant the protection (McAdam, 2011). In the words of the Inter-American Commission on Human Rights (2015):

The measures of complementary protection make it possible to regularize the stay of persons who are not recognized as refugees but whose return would be contrary to the general obligations of non-refoulement, contained in various human rights instruments (Inter-American Commission on Human Rights, 2015, para. 133).

Also, the durable solutions for refugees that could be applied to address climate forced migration, voluntary repatriation, local integration, and resettlement, are measures that may help to mitigate the climate change impacts on migration. Nation-States should operationalize solutions for climate migrants based on the needs of international protection, considering:

- Undertaking activities to facilitate voluntary repatriation and sustainable reintegration, in cooperation with relevant partners, as well as post-return monitoring.

- Exploring local integration options for certain groups, such as leave to remain and naturalization.

- Exploring resettlement options and quotas for specific groups, using resettlement strategically and coordinating resettlement needs with a view to adopting a regionwide approach (United Nations High Commissioner for Refugees, 2007, p. 187). 


\section{Preventive Measures in Case of Statelessness}

As mentioned above, statelessness as a consequence of climate change will be difficult to address, considering the lack of regulation and the novelty of the new situation of statelessness. Therefore, it is particularly important to take preventive measures that involve: 1) reduction of the impact of climate change, and 2) preparation for the moment when different States become uninhabitable. The fact that climate change is a reality cannot be ignored and international law must be prepared, according to the existing regulation on international human rights laws. In this sense, "the severity of the challenges would depend on the progression of sea-level rise. Initially, drastic consequences would affect only some low-lying States - in particular, several Pacific and Indian Ocean island-States" (Vidas, 2014, p. 73).

Consequently, international regulation concerning stateless persons as a result of climate change should be based on the importance of having a nationality, with the purpose of creating a special system of protection in receiving States, giving obligations and rights allowing the stateless person to keep his or her life and to adapt in the receiving State.

Also, the recognition of the stateless status is not enough to guarantee the protection of human rights of the person forced to migrate as a consequence of the uninhabitability or disappearance of the territory of their State, but it should be the beginning point for the development of legal measures to address this challenge.

\section{CONCLUSION}

As has been mentioned before, the impacts of climate change are starting to be revealed before the world expected them "[...] climate change continues unabated, there is a growing population of displaced men, women, and children whose homes have been rendered unlivable thanks to a wide spectrum of environmental disasters" (Lam, 2012, para. 1). That spectrum includes damage to settlements and infrastructure; alteration of ecosystems; disruption of water supply and food production; mortality; incidence of diseases and poor health, as a result of floods, wildfires, cyclones, heatwaves, and droughts caused by climate change (Intergovernmental Panel on Climate Change, 2014, p. 6), all of which have an impact on human society.

The number of environmentally affected and future stateless people in the world has started to rise and will continue to increase. Native Alaskans and low-lying island States of Oceania are the first communities facing climate change because of their geographic location and the traditional livelihoods that make them vulnerable to the difficulties of a warming world (Mellino, 2016, para. 3).

In the future, the estimation is that there will be "[ $[.$.$] from 25$ million to 1 billion environmental migrants by 2050, moving either within their countries or across borders, on 
a permanent or temporary basis, with 200 million being the most widely cited estimate" (International Organization for Migration, n.d., para. 15). Furthermore, considering the estimate of 200 million environmental refugees by 2050, this number:

[...] represent[s] nearly a four-fold increase in the number of displaced persons and refugees currently eligible for protection under the UNHCR mandate. And in 2007, the IPCC suggested that more than 600 million people currently living in low-lying coastal zones -438 million in Asia and 246 million in least developed countries- will be directly at risk to potential threats of climate change in this century. The so-called 'climate hotspots' low-lying islands, coastal regions, large river deltas, and underdeveloped regions- remain in danger of catastrophic environmental change. Under current International Law, any climate-induced, cross-border migrations from these areas would trigger little if any protections or assistance mechanisms that could help provide aid to them (Glahn, 2009, para. 13).

In view of the above, it is possible to say that the principal cause of statelessness is not only rising sea levels but also, environmental disasters, the lack of natural resources, and problems with food production and water supply.

The impacts of climate change are real and cannot be ignored. Millions will be internally displaced or will have to flee their countries on account of climate change. Also, entire populations could be forced to move to other countries since the disappearance of their States seems inevitable. Nevertheless, the relevant issue here is to prevent this catastrophe through the adoption of legislative measures at both the internal and international law levels to provide appropriate legal protection in accordance with present and future human rights standards.

\section{REFERENCES}

Alexander, H., \& Simon, J. (2014). Sinking Into Statelessness. Tilburg Law Review, 19(12), 20-25. doi:10.1163/22112596-01902003

Alexander, H., \& Simon, J. (2017). No Port, No Passport: Why Submerged States Can Have no Nationals. Washington International Law Journal Association, 26(2), 307-324.

Aminzadeh, S. (2007). A Moral Imperative: The Human Rights Implications of Climate Change. Hastings International \& Comparative Law Review, 30, 231- 265.

Asociación Americana para la Defensa del Ambiente. (2008). Guía de defensa ambiental: Construyendo la estrategia para el litigio de casos ante el Sistema Interamericano de Derechos Humanos. Mexico: AIDA.

Barnett, J. (2017). The dilemmas of normalising losses from climate change: Towards hope for Pacific atoll countries. Asia Pacific Viewpoint, 58(1), 3-13. doi: 10.1111/apv.12153 
Black, R., Arnell, N. W., Adger, W. N., Thomas, D., \& Geddes, T. (2012). Migration, environmental change, and the 'challenges of governance'. Environment and Planning C: Government and Policy, 30, 951 - 967.

Black, R., \& Collyer, M. (2014). Populations 'trapped' at times of crisis. Retrieved from http://www.fmreview.org/sites/fmr/files/FMRdownloads/en/crisis/black-collyer.pdf

Bates, D. (2002). Environmental Refugees? Classifying Human Migrations Caused by Environmental Change. Population and Environment, 23(5), 465-477.

Brown, O. (2007). Climate Change and Forced Migration: observations, projections and implications. (Rep. No. 2007/17). Retrieved from https://www.iisd.org/sites/default/files/publications/climate_forced_migration.pdf

Burleson, E. (2010). Climate Change Displacement to Refugee. Journal of Environmental Law \& Litigation, 25, 19-36.

Chapman, M. (2010). Climate Change and the Regional Human Rights Systems. Sustainable Development Law \& Policy, 37-38, 60-61.

Crawford, J. (1977). The criteria for statehood in international law. British Yearbook of International Law, 48(1), 93-182. doi.org/10.1093/bybil/48.1.93

European Commission. (2016). Climate Change: Paris Agreement. Retrieved from https://ec.europa.eu/clima/policies/international/negotiations_en

Feijen, L. (2012). Jane McAdam: Climate Change, Forced Migration, and International Law. Merkourios: Utrecht Journal of International and European Law, 28(75), Book Review, 61-64.

Fujibayashi, H., \& Nakayama, M. (2017). An Option to Avoid the Sudden Mass Influx of Migrants Resulting from Worldwide Environmental Threats. International Journal of Social Science Studies, 5(6), 1-8. doi: 10.111 14/ijsss.v5i6.2397.

Glahn, B. (2009, June 11). 'Climate refugees'? Addressing the international legal gaps Benjamin Glahn. The International Bar Association. Retrieved from https://www.ibanet.org/Article/NewDetail.aspx?ArticleUid=B51C02C1-3C27-4AE3B4C4-7E350EB0F442

Gogarty, B. (2011). Climate-Change Displacement: Current Legal Solutions to Future Global Problems. Journal of Law, Information and Science, 21(1),167-188.

IACtHR. The Right to Information on Consular Assistance in the Framework of the Guarantees of the due Process of Law. Advisory Opinion OC-16/99 of October 1, 1999. Series A No. 16.

IACtHR. Case of the Mayagna (Sumo) Awas Tingni Community v. Nicaragua. Merits, Reparations, and Costs. Judgment of August 31, 2001. Series C No. 79. 
IACtHR. Case of the Yakye Axa Indigenous Community v. Paraguay. Merits, Reparations, and Costs. Judgment of June 17, 2005. Series C No. 125.

IACtHR. Case of the Pueblo Bello Massacre v. Colombia. Merits, Reparations, and Costs. Judgment of January 31, 2006a. Series C No. 140.

IACtHR. Case of the Sawhoyamaxa Indigenous Community v. Paraguay. Merits, Reparations, and Costs. Judgment of March 29, 2006b. Series C No. 146.

IACtHR. Case of Kawas Fernández v. Honduras. Merits, Reparations, and Costs. Judgment of April 3, 2009. Series C No. 196.

IACtHR. Case of the Xákmok Kásek Indigenous Community v. Paraguay. Merits, Reparations, and Costs. Judgment of August 24, 2010. Series C No. 214.

IACtHR. Case of Luna López v. Honduras. Merits, Reparations, and Costs. Judgment of October 10, 2013a. Series C No. 269.

IACtHR. Case of Osorio Rivera and Family members v. Peru. Preliminary Objections, Merits, Reparations, and Costs. Judgment of November 26, 2013b. Series C No. 274.

IACtHR. The Environment and Human Rights (State obligations in relation to the environment in the context of the protection and guarantee of the rights to life and to personal integrity: interpretation and scope of Articles 4(1) and 5(1), in relation to Articles 1(1) and 2 of the American Convention on Human Rights). Advisory Opinion OC-23/17 of November 15, 2017. Series A No. 23.

Inter-American Commission on Human Rights. (2015). Human Mobility, Inter-American Standards. I. Title. II. Series: OAS. Official records; OEA/Ser.L.

Intergovernmental Panel on Climate Change. (2014). Summary for policymakers. In C.B. Field, V.R. Barros, D.J Dokken, K.J. Mach, M.D. Mastrandrea, T.E. Bilir, M. Chatterjee, K.L Ebi, Y.O. Estrada, R.C. Genova, B. Girma, E.S. Kissel, A.N. Levy, S. MacCracken, P.R. Mastrandrea \& L.L. White (Eds.), Climate Change 2014: Impacts, Adaptation, and Vulnerability. Part A: Global and Sectoral Aspects. Contribution of Working Group II to the Fifth Assessment Report of the Intergovernmental Panel on Climate Change (pp. 1-32). Cambridge, U.K \& New York, U.S.A: Cambridge University Press. Retrieved from http://www.ipcc.ch/pdf/assessmentreport/ar5/wg2/ar5 wgII spm en.pdf

International Organization for Migration. (n.d.). Migration, Climate Change and Environment. Retrieved from http://www.iom.int/complex-nexus\#estimates 
Jan, H. (2011). Statehood and State Extinction: Sea Level Rise and the Legal Challenges Faced by Low-Lying Island-States (Unpublished Master's Thesis). University of Groningen. $\quad$ Retrieved from https://www.academia.edu/6125630/Statehood and State Extinction Sea Level Ris $\mathrm{e}$ and the Legal Challenges Faced by Low-Lying IslandStates Table of contents

Kälin, W., \& Schrepfer, N. (2012). Protecting People Crossing Borders in the Context of Climate Change Normative Gaps and Possible Approaches. UNHCR Legal and Protection Policy Research Series. Retrieved de http://www.unhcr.org/4f33f1729.pdf

Kibreab, G. (2009). Climate Change and Human Migration: A Tenuous Relationship. Fordham Environmental Law Review, 20(2), 357-401.

Kuusipalo, R. (2017). Exiled by Emissions - Climate Change Related Displacement and Migration in International Law: Gaps in Global Governance and the Role of the UN Climate Convention. Vermont Journal of Environmental Law, 18, 614-647.

Lam, A. (2012, August 23). Number of Environmental Refugees to Grow to 50 Million by 2020. Earth Island Journal. Retrieved from http://www.earthisland.org/journal/index.php/articles/entry/number of environmental refugees to grow to 50 million by $2020 /$

Lixinski, L. (2010). Treaty Interpretation by the Inter-American Court of Human Rights: Expansionism at the Service of the Unity of International Law. European Journal of International Law, 21(3), 585-604. doi.org/10.1093/ejil/chq047

Llain, S. (2015). "Violations to the Principle of Non-Refoulement under the Asylum Policy of the United States.” Anuario Mexicano de Derecho Internacional, 15, 283-322.

Mandal, R. (2005). Protection Mechanisms Outside of the 1951 Convention (“Complementary Protection") (PPLA/2005/02). Geneva, Switzerland: UNHCR.

Mayer, B. (2013). Climate Migration Governance. In W. Leal, H. Polo, \& A. Singh (Eds.), Handbook of Climate Change Adaptation. Vol. 2, Policy and Climate Change (pp. 828838). Berlin: Springer.

McAdam, J. (2010). 'Disappearing States', Statelessness and the Boundaries of International Law. UNSW Law Research Paper No. 2010-2, (2), 1-23. doi:10.5040/9781472565211.ch-006.

McAdam, J. (2011). Climate Change Displacement and International Law: Complementary Protection Standards (PPLA/2011/03). Geneva, Switzerland: UNHCR.

Mellino, C. (2016, January 05). Meet the World's First Climate Refugees. EcoWatch. Retrieved from https://www.ecowatch.com/meet-the-worlds-first-climate-refugees$\underline{1882143026 . h t m l}$ 
Montevideo Convention on the Rights and Duties of States. (1934). Signed at Montevideo, 26 December $1933 . \quad$ Retrieved from https://www.ilsa.org/Jessup/Jessup15/Montevideo\%20Convention.pdf

Naser, M. (2010). Climate Change and Forced Displacement: Obligation of States under International Human Rights Law. Sri Lanka Journal of International Law, 22(2), 117 164.

Office of the United Nations High Commissioner for Human Rights. (2009). Report of the Office of the United Nations High Commissioner for Human Rights on the Relationship Between Climate Change and Human Rights (A/HRC/10/61). Switzerland, Geneva: United Nations.

Park, S., \& UNHCR. (2011). Climate Change and the Risk of Statelessness: The Situation of Low-lying Island States (PPLA/2011/04). Switzerland, Geneva: UNHCR.

Rankin, J. (2016, April 20). Council of Europe condemns EU's refugee deal with Turkey. The Guardian. Retrieved from https://www.theguardian.com/world/2016/apr/20/eu-refugee-deal-turkey-condemnedcouncil-of-europe

Norwegian Refugee Council. (2011). The Nansen Conference: Climate Change and Displacement in the 21st Century. Oslo, Norway: Norwegian Refugee Council. Retrieved from http://www.unhcr.org/4ea969729.pdf

Tomkiw, L. (2015, October 11). Kiribati Climate Change Relocation Refugee Crisis? Sinking Low-Lying Island Nations In Pacific, Indian Oceans Seeking Solutions Before It's Too Late. International Business Times. Retrieved from http://www.ibtimes.com/kiribati-climate-change-relocation-refugee-crisis-sinkinglow-lying-island-nations-2127526

Toscano, J. (2017). Climate Change Displacement and Forced Migration: An International Crisis. Arizona Journal of Environmental Law and Policy, 6(1), 457-490.

Thornton, F. (2012). Climate Change, Displacement and International Law: Between Crisis and Ambiguity. Australian Year Book of International Law, 30, 147-160.

United Nations. (2015). Paris Agreement. Paris: United Nations, I-54113, pp.88-112. Retrieved from https://treaties.un.org/doc/Publication/UNTS/No\%20Volume/54113/Part/I-541130800000280458f37.pdf

UN General Assembly. (2015). Transforming our world: the 2030 Agenda for Sustainable Development A/RES/70/1, p. $14 . \quad$ Retrieved from https://www.refworld.org/docid/57b6e3e44.html 
United Nations High Commissioner for Refugees. (2004). Brazil Declaration and Plan of Action. Retrieved from https://www.acnur.org/5b5101644.pdf

United Nations High Commissioner for Refugees. (2009). Climate Change and Statelessness: An Overview. Bonn, Germany: UNHCR.

United Nations High Commissioner for Refugees. (2007). The 10-Point Plan of Action on Refugee Protection and Mixed Migration. Retrieved from http://www.unhcr.org/the-10point-plan-in-action.html

Vidas, D. (2014). Sea-Level Rise and International Law: At the Convergence of Two Epochs. Climate Law, 4, 70-84. doi:10.1163/18786561-00402006.

Warren, P. (2016). Forced Migration after Paris COP21: Evaluating the "Climate Change Displacement Coordination Facility”. Columbia Law Review, 116(8), 2103-2144.

Wyman, K. (2013). Responses to Climate Migration. Harvard Environmental Law Review, $37,167-217$.

Zetter, R. (2015). Protection in Crisis: Forced Migration and Protection in a Global Era (Rep.). Retrieved from https://www.migrationpolicy.org/research/protection-crisisforced-migration-and-protection-global-era

Zounuzy, A. (2012). International Law and The Criteria for Statehood (Unpublished Master's Thesis). University of Tilburg. Retrieved from http://webcache.googleusercontent.com/search?q=cache:nSJmja7PQPIJ:arno.uvt.nl/sh ow.cgi?fid $=121942 \& \mathrm{~cd}=1 \& \mathrm{hl}=\mathrm{en} \& \mathrm{ct}=\mathrm{clnk} \& \mathrm{gl}=\mathrm{co}$ 